Eli Laeli Warlina, S. Pd. SD.

Penggunaan Model Pembelajaran Kooperatif Tipe Think Pair Share (TPS) untuk

Meningkatkan Hasil Belajar Membandingkan Dua Bilangan Cacah Siswa Kelas II B SD

Negeri Pajambon

\title{
PENGGUNAAN MODEL PEMBELAJARAN KOOPERATIF TIPE THINK PAIR SHARE (TPS) UNTUK MENINGKATKAN HASIL BELAJAR MEMBANDINGKAN DUA BILANGAN CACAH SISWA KELAS II B SD NEGERI PAJAMBON
}

Eli Laeli Warlina, S. Pd. SD.

SD Negeri Pajambon Kuningan

\begin{abstract}
Pengutipan: Warlina E. L. (2019). Penggunaan model pembelajaran kooperatif tipe think pair share (tps) untuk meningkatkan hasil belajar membandingkan dua bilangan cacah siswa Kelas II B SD Negeri Pajambon. Pedagogi: Jurnal Penelitian Pendidikan, 6(1), hlm 56-64.
\end{abstract}

Diajukan: 05-04-2019 Diterima: 30-05-2019 Diterbitkan: 31-05-2019

\begin{abstract}
ABSTRAK
Penelitian Tindakan Kelas (Class Action Research) ini berjudul "Penggunaan Model Pembelajaran Kooperatif Tipe Think Pair Share (TPS) Untuk Meningkatkan Hasil Membandingkan Dua Bilangan Cacah Siswa Kelas II B SD Negeri Pajambon”. Tujuannya adalah untuk mengetahui peningkatan hasil belajar membandingkan dua bilangan cacah siswa kelas II B SD Negeri Pajambon melalui penggunaan model pembelajaran kooperatif tipe Think Pair Share (TPS). Metode penelitian ini adalah penelitian tindakan kelas. Penelitian dilaksanakan dalam 2 siklus perbaikan, dan masing-masing siklus 2 pertemuan. Subjek penelitian ini adalah siswa kelas II B SD Negeri 4 Pajambon Kabupaten Kuningan tahun 2018 dengan jumlah 20 siswa pada pembelajaran membandingkan dua bilangan cacah. Penelitian ini menggunakan penelitian tindakan (action research) sebanyak 2 siklus dan 2 pertemuan. Setiap siklus terdiri dari empat tahap yaitu: rancangan, kegiatan dan pengamatan, refleksi, dan observasi. Data yang diperoleh berupa hasil tes tanya jawab, lembar observasi kegiatan belajar mengajar. Hasil penelitian pada tes evaluasi pertemuan 1 memperoleh rata-rata kelas sebesar 61, prosentase ketuntasan sebesar 20\%, sedangakan pada pertemuan 2 rata-rata kelas sebesar 68,5 dan prosentase ketuntasan sebesar 30\%. Sedangkan pada siklus II rata-rata kelas pada pertemuan 1 sebesar 77 dengan prosentase ketuntasan sebesar $70 \%$, pada pertemuan 2 rata-rata kelas sebesar 84 dengan prosentase ketuntasan sebesar 85\%. Dari hasil di atas, maka nilai dan prosentase ketuntasan selalu mengalami kenaikan pada setiap siklusnya, baik pertemuan 1 maupun pertemuan 2. Sehingga dapat disimpulkan bahwa penggunaan model pembelajaran kooperatif tipe Think Pair Share (TPS) dapat meningkatkan hasil belajar membandingkan dua bilangan cacah siswa kelas II B SD Negeri Pajambon.
\end{abstract}

Kata Kunci: Hasil Belajar, Pembelajaran Kooperatif, Think Pair Share 


\section{PENDAHULUAN}

Matematika sebagai salah satu ilmu dasar dewasa ini berkembang demikian pesat, baik materi maupun terapannya. Kemajuan ilmu pengetahuan dan teknologi sekarang ini tidak terlepas dari peranan matematika. Penguasaan matematika sangat penting dalam mempercepat kemajuan ilmu pengetahuan dan teknologi (IPTEK). Banyak anggapan dari masyarakat bahwa guru atau pendidik di kalangan SD kurang profesional. Hal ini disebabkan bermacam-macam alasan ataupun kendala yang dihadapi oleh pendidik itu sendiri. Di antaranya, pembelajaran yang digunakan masih konvesional dengan metode ceramah dan berdasarkan materi pada buku pegangan. Tetapi di antara kendala-kendala yang ada, kendala yang paling pokok adalah pembelajaran matematika tidak disertai dengan media alat peraga. Seorang pendidik dituntut keprofesionalannya dalam melaksanakan tugasnya untuk mencapai tujuan visi, misi sekolah. Peneliti sebagai pendidik di SD Negeri Pajambon yang masuk dalam wilayah Kabupaten Kuningan, merasa terpanggil untuk ikut mengembangkan dan memajukan SD.

Sesuai dengan eksistensinya di sekolah, tugas utama seorang guru adalah mengajar sehingga setiap akan mengajar seseorang guru harus mempersiapkan suatu cara bagaimana agar yang diajarkan kepada siswa itu dapat diterima serta dapat dipahami dengan mudah. Selanjutnya dalam proses belajar mengajar peranan guru dalam memilih metode mana yang akan digunakan sangatlah penting. Hal ini disebabkan karena tugas utama guru adalah menyampaikan bahan pelajaran kepada siswa dengan harapan siswa dapat menerima dan memahami bahan pelajaran dengan mudah. Mengingat bahwa metode adalah cara yang dalam fungsinya merupakan suatu alat untuk mencapai tujuan, maka makin baik metode itu makin efektif pula pencapaian tujuan. Sehingga dapat dikatakan bahwa apabila guru dalam memilih metode mengajar tepat dan dilaksanakan sesuai dengan prosedur, diharapkan siswa dapat menerima dan memahami dengan baik apa yang diajarkan oleh guru.

Pembelajaran matematika di Sekolah Dasar memerlukan kegiatan yang praktis mamapu mengarahkan pada pemahaman konsep matematika. Sehingga guru harus dapat menciptakan dan mempersiapkan siswa agar dapat menggunakan matematika dan pola pikir matematika dalam kehidupan sehari-hari, yaitu pembelajaran yang terprogram sesuai dengan tumbuh kembang peserta didik secara optimal.

Menurut Ruseffendi (MKPBM, 2001: 25) 'konsep matematika tersusun secara hierarkis, terstruktur, logis, dan sistematis mulai dari konsep yang paling sederhana sampai yang paling kompleks. Dalam matematika terdapat topik atau konsep persyaratan sebagai dasar untuk memahami topic atau konsep selanjutnya.

Dalam pembelajaran membandingkan dua bilangan cacah dan untuk menanamkan konsep membandingkan dua bilangan cacah, maka seorang guru menanamkan pembelajarannya memerlukan suatu pendekatan matematika, agar konsep yang disajikan bisa diterima oleh siswa. Salah satunya adalah melalui penggunaan model pembelajaran Think Pair Share yang memberikan siswa lebih banyak waktu untuk berfikir, mejawab dan saling membantu satu sama lain.

Hasil belajar siswa kelas II pada mata pelajaran Matematika masih belum mencapai apa yang diharapkan. Terlihat dari nilai siswa yang mendapat nilai rata-ratanya belum mencapai Kriteria Ketuntasan Minimal (KKM) 70 dan prosentase ketuntasan belum mencapai prosentase ketuntasan minimal $(80 \%)$. Dari 20 orang siswa hanya 6 orang siswa yang mencapai Kriteria Keuntasan Minimal (KKM) 70, sisanya 14 orang siswa masih dibawah Kriteria Ketuntasan Minimal (70) dan belum mencapai prosentase ketuntasan minimal (80\%). Faktor penyebabnya adalah pemahaman siswa terhadap suatu konsep pembelajaran masih rendah. Dengan pemahaman yang rendah maka hasil belajarpun akan rendah.

Salah satu upaya untuk mengatasi rendahnya aktivitas dan hasil belajar siswa, adalah melalui penggunaan model pembelajaran Think Pair Share (TPS), yang dianggap mampu 
Eli Laeli Warlina, S. Pd. SD.

Penggunaan Model Pembelajaran Kooperatif Tipe Think Pair Share (TPS) untuk

Meningkatkan Hasil Belajar Membandingkan Dua Bilangan Cacah Siswa Kelas II B SD

Negeri Pajambon

memfasilitasi proes pembelajaran siswa untuk mencapai kebermaknaan belajar sehingga tujuan pembelajaran yang diharapkan dapat lebih maksimal.

Pembelajaran dengan model Think Pair Share (TPS), maksudnya adalah memberikan siswa lebih banyak waktu untuk berfikir, emjawab dan saling membantu satu sama lain. Salah satu manfaat yang dapat diperoleh dari pembelajaran model Think Pair Share (TPS) adalah meningkatkan partisipasi siswa terhadap pembelajaran.

Tipe Think Pair Share (TPS) dikembangkan oleh Frank Lyman. Tipe TPS memberikan kesempatan lebih banyak kepada siswa untuk dikenali dan menunjukan partisipasi mereka kepada orang lain. Tipe ini bisa digunakan dalam semua mata pelajaran dan untuk semua tingkatan usia anak didik. Diharapkan melalui model pembelajaran kooperatif tipe Think Pair Share (TPS) dapat meningkatkan hasil belajar peserta didik pada pembelajaran membandingkan dua bilangan cacah.

Dari uraian di atas penulis tertarik untuk melaksanakan Penelitian Tindakan Kelas (PTK) dengan judul "Penggunaan Model Pembelajaran Kooperatif Tipe Think Pair Share (TPS) Untuk Meningkatkan Hasil Belajar Membandingkan Dua Bilangan Cacah Siswa Kelas IIB SD Negeri Pajambon".

\section{METODE PENELITIAN}

Jenis Penelitian

Penelitian ini merupakan Penelitian Tindakan Kelas (Class Action Research) menggunakan Model Pembelajaran Kooperatif Tipe Think Pair Share (TPS) untuk Meningkatkan Hasil Belajar Membandingkan Dua Bilangan Cacah Siswa Kelas II B SD Negeri Pajambon Kuningan.

Setting Penelitian

Penelitian ini dilaksanakan di kelas II B SD Negeri Pajambon Desa Pajambon Kecamatan Kramatmulya Kabupaten Kuningan. Waktu pelaksanaan perbaikan pembelajaran mata pelajaran mulai dilaksanakan dari tanggal 6 September 2018 sampai dengan 11 Oktober 2018.

Subjek Penelitian

Subjek penelitian ini adalah siswa kelas II B SD Negeri Pajambon Kabupaten Kuningan sebanyak 20 siswa yang terdiri dari 5 orang siswa laki-laki dan 15 orang siswa perempuan. Siswa kelas ini memiliki karakteristik yang beragam, baik dari prestasi belajar maupun partisipasi orang tua dalam keberhasilan pendidikan anaknya.

Prosedur Penelitian

Sesuai dengan karakteristiknya, rancangan penelitian tindakan kelas ini dilaksanakan melalui 4 tahap kegiatan. Prosedur pelaksanaan penelitian ini mengikuti prinsip prinsip dasar penelitian tindakan yang telah umum dilakukan. Menurut Waseno (1994) proses penelitian tindakan adalah suatu proses daur ulang dari perencanaan, tindakan, observasi dan refleksi (perenungan, pemikiran, dan evaluasi). Penelitian yang dilakukan direncanakan terdiri dari dua siklus dan dua pertemuan.

Teknik Pengumpulan Data

Data dalam PTK adalah segala bentuk informasi yang terkait dengan kondisi, proses, dan keterlaksanaan pembelajaran, serta hasil belajar yang diperoleh siswa. Data yang diperoleh yaitu data kualitatif yang berupa angka atau bilangan, baik yang diperoleh dari hasil pengukuran maupun diperoleh dengan cara mengubah data kualitatif menjadi data kuantitatif. 
Data kuantitatif dianalisis secara deskriptif dengan cara: (a) Menghitung jumlah; (b) Menghitung rata-rata (rerata); (c) Menghitung nilai persentase; (d) Membuat grafik.

Teknik Analisis Data

Analisis dan pengolahan data dilakukan selama penelitian dari awal hingga akhir penelitian. Data diperoleh dari kumpulan instrument dan dideskrpsikan untuk diambil kesimpulannya. Adapun langkah analisis data dilakukan dengan cara sebagai berikut: (a) Penyeleksian data yaitu pemilihan data yang akurat yang dapat menjawab fokus penelitian dan memberikan gambaran tentang hasil penelitian; (b) Pengklasifikasian data yaitu pengelompokan data yang telah diseleksi, pengklasifikasian data bertujuan untuk memudahkan pengolahan data dan pengambilan keputusan berdasarkan presentase yang dijadikan pegangan; (c) Pentabulasian data, dilakukan setelah data diklasifikasikan berdasarkan tujuan penelitian kemudian ditabulasikan dalam bentuk tabel dengan tujuan untuk mengetahui frekuensi masingmasing alternatif jawaban yang satu dengan yang lain agar mempermudah membaca data.

Ketiga komponen tersebut dijadikan pegangan dalam meningkatkan analisis menuju pencapaian dan perbaikan pembelajaran di SD. Dengan demikian dapat memberikan kejelasan terhadap pelaksanaan kegiatan yang dituangkan sehingga orang lain dapat membaca dengan mudah.

Indikator Keberhasilan

Peningkatan indikatornya adalah adanya peningkatan prestasi belajar siswa dari kurang baik menjadi baik. Peningkatan prestasi belajar pada pembelajaran membandingkan dua bilangan cacah siswa kelas II B SD Negeri Pajambon melalui penggunaan penggunaan model pembelajaran kooperatif tipe Think Pair Share (TPS) indikatornya adalah nilai evaluasi siswa mencapai Kriteria Ketuntasan Minimal (70) dan prosentase ketuntasan mencapai prosentase ketuntasan minimal $(80 \%)$.

\section{HASIL PENELITIAN DAN PEMBAHASAN}

Setelah melakukan penelitian sebanyak 2 siklus dan masing masing siklus terdiri dari dua pertemuan diperoleh hasil penelitian sebagai berikut. Hasil penilaian siswa siklus I dapat dilihat pada tabel di bawah ini.

Tabel 1. Data Hasil Evaluasi Perbaikan Siklus I

\begin{tabular}{clcc}
\hline \multirow{2}{*}{ No } & \multicolumn{2}{c}{ Kriteria } & \multicolumn{2}{c}{ Siklus I } \\
\cline { 3 - 4 } & & Pertemuan 1 & Pertemuan 2 \\
\hline $\mathbf{1}$ & Nilai Tertinggi & 80 & 80 \\
\hline $\mathbf{2}$ & Nilai Terendah & 40 & 50 \\
\hline $\mathbf{3}$ & Rata-rata Kelas & 61 & 68,5 \\
\hline $\mathbf{4}$ & Prosentase Ketuntasan & $20 \%$ & $30 \%$ \\
\hline
\end{tabular}

Pada hasil tes evaluasi pertemuan 1 memperoleh rata-rata kelas sebesar 61, persentase ketuntasan sebesar 20\%, sedangakan pada pertemuan 2 rata-rata kelas sebesar 68,5 dan persentase ketuntasan sebesar $30 \%$.

Nilai hasil pembelajaran pada siklus II dapat dilihat pada tabel berikut.

Tabel 2. Data Hasil Evaluasi Perbaikan Siklus II

\begin{tabular}{clcc}
\hline \multirow{2}{*}{ No } & \multicolumn{2}{c}{ Kriteria } & \multicolumn{2}{c}{ Siklus II } \\
\cline { 3 - 4 } & & Pertemuan 1 & Pertemuan 2 \\
\hline $\mathbf{1}$ & Nilai Tertinggi & 90 & 100 \\
\hline $\mathbf{2}$ & Nilai Terendah & 60 & 70 \\
\hline $\mathbf{3}$ & Rata-rata Kelas & 77 & 84 \\
\hline $\mathbf{4}$ & Prosentase Ketuntasan & 70 & 85 \\
\hline
\end{tabular}


Eli Laeli Warlina, S. Pd. SD.

Penggunaan Model Pembelajaran Kooperatif Tipe Think Pair Share (TPS) untuk

Meningkatkan Hasil Belajar Membandingkan Dua Bilangan Cacah Siswa Kelas II B SD

Negeri Pajambon

Pada siklus II hasil tes individu pada pertemuan 1 rata-rata kelas sebesar 77 dengan prosentase ketuntasan sebesar $70 \%$, pada pertemuan 2 rata-rata kelas sebesar 84 dengan prosentase ketuntasan sebesar $85 \%$.

Pembahasan hasil penelitan dilakukan berdasarkan rumusan masalah dan hasil penelitian. Pembahasan dilakukan dengan menggunakan metode analisis yang telah ditentukan serta berpedoman pada indikator keberhasilan. Indikator keberhasilan menyatakan bahwa penelitian dinyatakan berhasil apabila rata rata hasil belajar mencapai minimal 70 dengan prosentase ketuntasan $80 \%$.

Hasil penelitian siklus I dapat dilihat pada tabel, pada tabel tersebut membandingkan perolehan hasil penelitan pada siklus I pertemuan 1 dan siklus I pertemuan 2. Hasil tes evaluasi pertemuan 1 memperoleh rata-rata kelas sebesar 61 dengan prosentase ketuntasan sebesar $20 \%$. Rata-rata nilai pertemuan I tersebut belum mecapai rata-rata nilai minimal $61(61<70)$. Begitu pula prosentse ketuntasan baru mencapai $20 \%$ belum mencapai prosentase minimal $80 \%$ (20\% $<80 \%)$.

Hasil Penelitian pertemuan 2 memperoleh rata-rata kelas sebesar 68,5 dan prosentase ketuntasan sebesar $30 \%$. Bila merujuk pada indikator keberhasilan, maka hasil penelitian siklus I pertemuan 2 ini pun belum berhasil karena baik nilai rata-rata $(68,5)$, maupun prosentase ketuntasan (30\%) belum mecapai rata-rata nilai minimal (70) dan prosentase ketuntasan minimal $(80 \%)$. Namun demikian baik nilai rata-rata kelas maupun prosentase ketuntasan pada pertemuan 2 lebih besar dari nilai rata-rata dan prosentase ketuntasan pada pertemuan 1 . Untuk lebih jelasnya perhatikan gambar berikut.

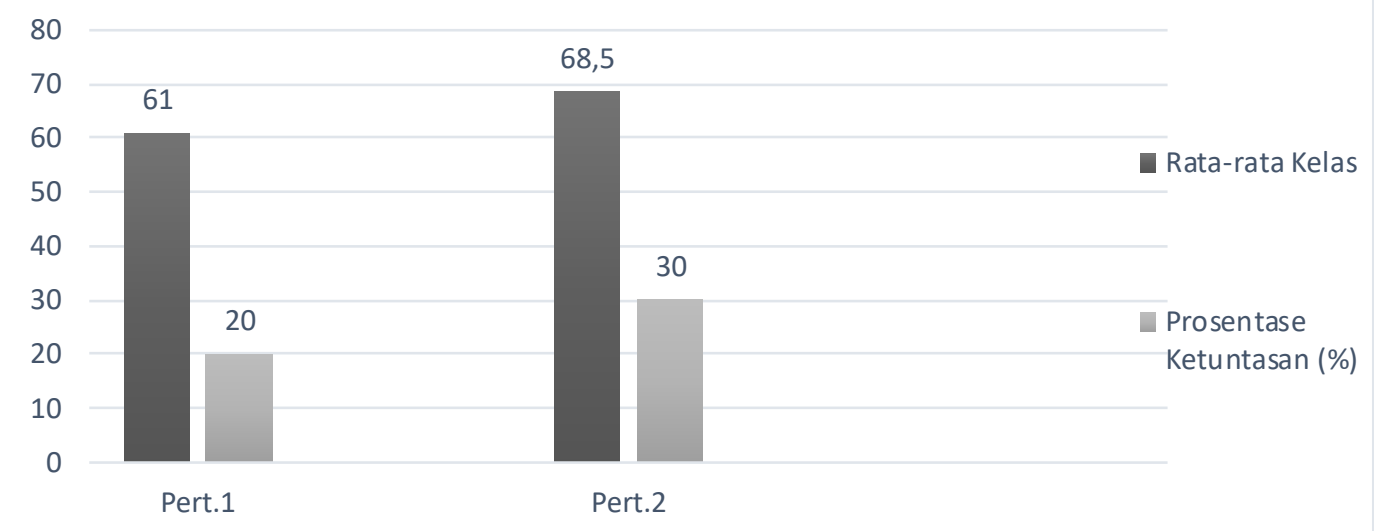

Gambar 1. Data Hasil Evaluasi Perbaikan Siklus I

Hasil penelitian siklus 2 dapat dilihat pada tabel, pada tabel tersebut membandingkan perolehan hasil penelitan pada siklus II pertemuan 1 dan siklus II pertemuan 2 . Hasil tes evaluasi pertemuan 1 memperoleh rata-rata kelas sebesar 77 dengan prosentase ketuntasan sebesar 70\%. Rata-rata nilai pertemuan I tersebut sudah mecapai rata-rata nilai minimal 70 (77 $>70$ ). Namun prosentse ketuntasan baru mencapai $70 \%$ belum mencapai prosentase minimal $80 \%(70 \%<80 \%)$.

Hasil Penelitian pertemuan 2 memperoleh rata-rata kelas sebesar 84 Rata rata nilai siklus II pertemuan 2 seperti pada pertemuan 1 telah mencapai rata-rata minimal 70, bahkan lebih tinggi dari rata-rata nilai pertemuan pertama $(84$ >77). Prosentase ketuntasan siklus II pertemuan 2 adalah sebesar $85 \%$ telah mencapai prosentase miniml $80 \%$ bahkan lebih. Bila merujuk pada indikator keberhasilan, maka hasil penelitian siklus II pertemuan 2 telah berhasil karena baik nilai rata-rata (84), maupun prosentase ketuntasan $(85 \%)$ sudah mecapai rata-rata nilai minimal (70) dan prosentase ketuntasan minimal (80\%). Dan terjadi peningkatan nilai 
rata-rata kelas maupun prosentase ketuntasan pada pertemuan 2 lebih besar dari nilai rata-rata dan prosentase ketuntasan pada pertemuan 1. Untuk lebih jelasnya perhatikan gambar berikut.

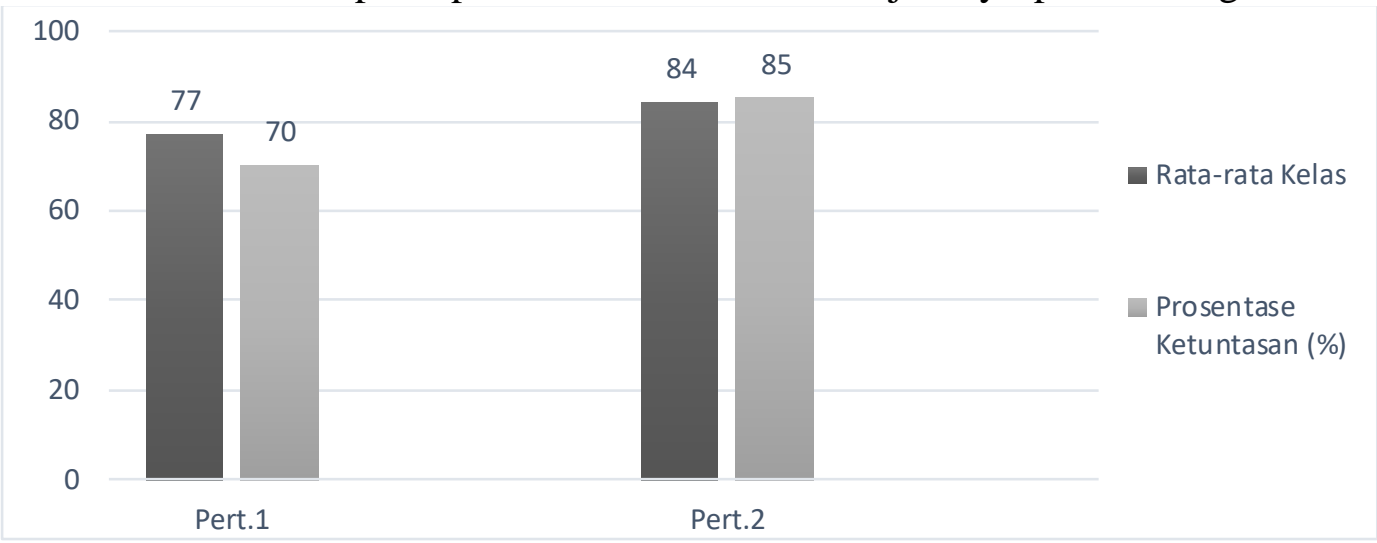

Gambar 2. Data Hasil Evaluasi Perbaikan Siklus 2

Hasil penelitian siklus 1 dan siklus 2 sebagaimana telah diuraikan di atas diringkaskan pada tabel. Berdasarakan tabel tersebut dapat dilihat peningkatan nilai tertinggi, nilai terendah, nilai rata-rata hasil belajar dan Prosentasi ketuntasan. Rata-rata hasil belajar meningkat dari 61 pada siklus I pertemuan 1, menjadi 68,5 pada siklus I pertemuan 2, 77 pada siklus II pertemuan 1 dan menjadi 84 pada siklus II pertemuan 2.

Tabel 3. Rekapitulasi Data Hasil Evaluasi Perbaikan Siklus I dan Siklus II

\begin{tabular}{clcccc}
\hline \multirow{2}{*}{ No } & \multirow{2}{*}{ Kriteria } & \multicolumn{2}{c}{ Siklus I } & \multicolumn{2}{c}{ Siklus II } \\
\cline { 3 - 5 } & & Pert.1 & Pert.2 & Pert.1 & Pert.2 \\
\hline $\mathbf{1}$ & Nilai Tertinggi & 80 & 80 & 90 & 100 \\
\hline $\mathbf{2}$ & Nilai Terendah & 40 & 50 & 60 & 70 \\
\hline $\mathbf{3}$ & Rata-rata Kelas & 61 & 68,5 & 77 & 84 \\
\hline $\mathbf{4}$ & Prosentase Ketuntasan $(\%)$ & $20 \%$ & $30 \%$ & $70 \%$ & $85 \%$ \\
\hline
\end{tabular}

Berdasarkan data tersebut, walaupun telah terjadi peningkatan pada rata-rata kelas dari siklus I pertemuan 1 ke pertemuan 2 namun penelitian dinyatakan baru dinyatakan berhasil pada siklus II. Sementara dari prosesntasi ketuntasan terjadi peningkatan dari $20 \%$ pada siklus I pertemuan 1, menjadi $30 \%$ pada siklus I pertemuan $2,70 \%$ pada siklus II pertemuan 1 menjadi $85 \%$ pada siklus II pertemuan 2. Dengan demikian berdasarakan prersentasi ketuntasan penelitian baru dinyatakan berhasi pada pertemuan 2 siklus II.

Peningkatan hasil belajar pada setiap pertemuan pada siklus I dan Siklus II, lebih jelas dapat dilihat pada gambar.

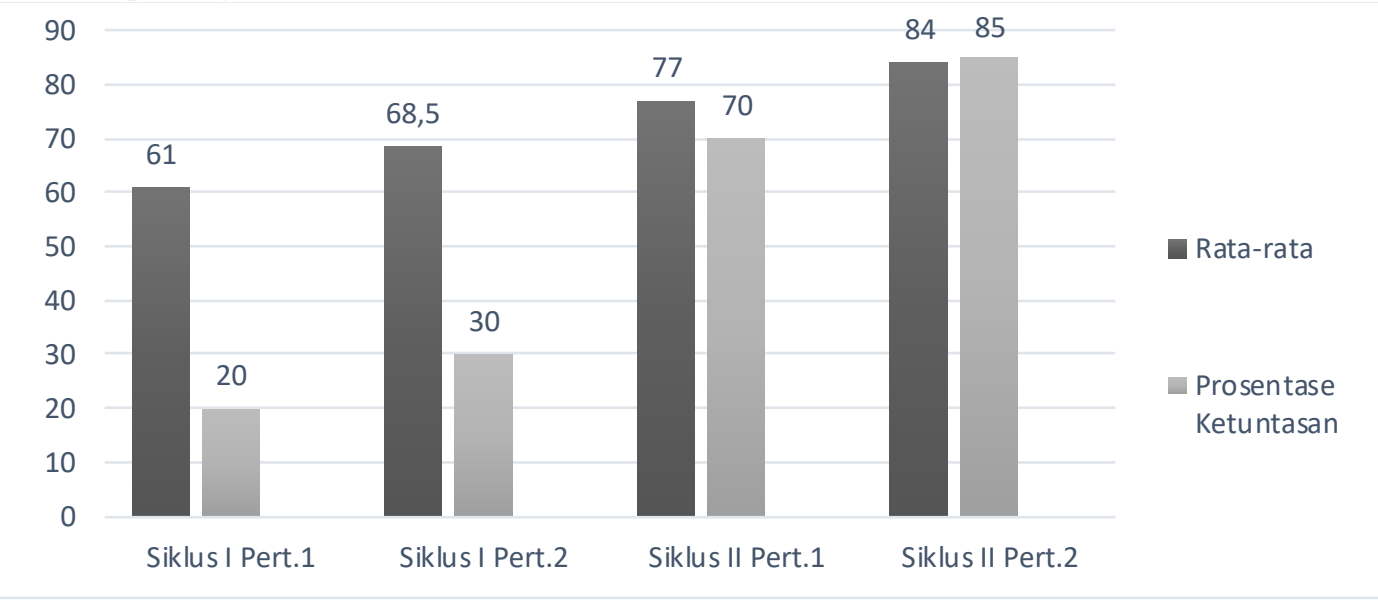

Gambar 3. Rekapitulasi Data Hasil Perbaikan Siklus I dan Siklus II 
Eli Laeli Warlina, S. Pd. SD.

Penggunaan Model Pembelajaran Kooperatif Tipe Think Pair Share (TPS) untuk

Meningkatkan Hasil Belajar Membandingkan Dua Bilangan Cacah Siswa Kelas II B SD

Negeri Pajambon

Berdasarkan pembahasan setiap siklus, maka secara keseluruhan telah terjadi peningkatan hasil belajar dari silklus 1 pertemuan 1 baik pada nilia rata-rata kelas maupun persentasi ketuntasan, dimana penelitian mencapai kriteria keberhasilan saat baik nilai rata-rata kelas maupuan prosentasi ketuntasan mencapai kriteria keberhasilan, 70 dan $80 \%$, yaitu pada siklus II pertemuan 2 sebesar 84 untuk rata-rata kelas dan $85 \%$ untuk prosentase penilaian.

Kegiatan yang dilakukan teman sejawat untuk mengobservasi kinerja guru dalam proses perbaikan pembelajaran siklus I dan II mata pelajaran Matematika dideskripsikan pada tabel di bawah ini.

Tabel 4. Rekapitulasi Hasil Observasi Perbaikan Siklus I dan II

\begin{tabular}{|c|l|c|c|c|c|}
\hline \multirow{2}{*}{ No } & \multirow{2}{*}{ Perilaku Guru yang Diamati } & \multicolumn{3}{|c|}{ Kemunculan } \\
\cline { 3 - 6 } & & \multicolumn{2}{|c|}{ Siklus I } & \multicolumn{2}{|c|}{ Siklus II } \\
\hline & & Ada & Tidak & Ada & Tidak \\
\hline $\mathbf{1}$ & $\begin{array}{l}\text { Mengkondisikan siswa ke arah } \\
\text { situasi pembelajaran yang kondusif }\end{array}$ & $\sqrt{ }$ & & $\sqrt{ }$ & \\
\hline $\mathbf{2}$ & $\begin{array}{l}\text { Mengkaitkan antara materi yang } \\
\text { diajarkan dengan kehidupan sehari- } \\
\text { hari }\end{array}$ & & $\sqrt{ }$ & $\sqrt{ }$ & \\
\hline $\mathbf{3}$ & Memberi tahu tujuan pembelajaran & $\sqrt{ }$ & & $\sqrt{ }$ & \\
\hline $\mathbf{4}$ & $\begin{array}{l}\text { Guru menyampaikan dan } \\
\text { menjelaskan materi pembelajaran } \\
\text { secara sistematis }\end{array}$ & $\sqrt{ }$ & & $\sqrt{ }$ & \\
\hline $\mathbf{5}$ & $\begin{array}{l}\text { Mengelompokan dan membimbing } \\
\text { siswa untuk diskusi }\end{array}$ & & $\sqrt{ }$ & $\sqrt{ }$ & \\
\hline $\mathbf{6}$ & $\begin{array}{l}\text { Mengkondisikan kelompok untuk } \\
\text { menyelesaian soal }\end{array}$ & $\sqrt{ }$ & & $\sqrt{ }$ & \\
\hline $\mathbf{7}$ & $\begin{array}{l}\text { Melaksanakan tanya jawab dengan } \\
\text { siswa terhadap materi yang kurang } \\
\text { dipahami }\end{array}$ & $\sqrt{ }$ & & $\sqrt{ }$ & \\
\hline $\mathbf{8}$ & Memberikan pekerjaan rumah & $\sqrt{ }$ & & $\sqrt{ }$ & \\
\hline 9 & $\begin{array}{l}\text { Mengkondisikan siswa ke arah } \\
\text { situasi pembelajaran yang kondusif }\end{array}$ & $\sqrt{ }$ & & $\sqrt{ }$ & \\
\hline & Jumlah komponen & $\mathbf{7}$ & $\mathbf{2}$ & $\mathbf{9}$ & $\mathbf{0}$ \\
\hline & Prosentase \% & $\mathbf{2 2 , 2 2}$ & $\mathbf{1 0 0}$ & $\mathbf{0}$ \\
\hline
\end{tabular}

Proses perbaikan pembelajaran yang dilakukan pada siklus I, penggunaan model pembelajaran kooperatif tipe Think Pair Share (TPS) yang digunakan kurang efektif dan hanya terpusat pada siswa yang pintar saja,. Sedangkan pada siklus II penggunaan penggunaan model pembelajaran kooperatif tipe Think Pair Share (TPS) untuk menjelaskan materi pembelajaran membandingkan dua bilangan cacah sudah efektif dan intensitas bimbingan guru terhadap siswa yang kurang paham ditingkatkan, sehingga siswa dapat memahami proses melalui masukan dari teman kelompok dan guru.

\section{SIMPULAN DAN SARAN}

Simpulan

Berdasarkan hasil penelitian tindakan kelas, maka penulis menyimpulkan bahwa penggunaan model pembelajaran kooperatif tipe Think Pair Share (TPS) dapat meningkatkan hasil belajar membandingkan dua bilangan cacah siswa kelas II B SD Negeri Pajambon. Hal ini bisa dilihat dari rata-rata hasil belajar meningkat dari 61 pada siklus I pertemuan 1, menjadi 
68,5 pada siklus I pertemuan 2, 77 pada siklus II pertemuan 1 dan menjadi 84 pada siklus II pertemuan 2. Sementara dari prosesntasi ketuntasan terjadi peningkatan dari $20 \%$ pada siklus I pertemuan 1, menjadi $30 \%$ pada siklus I pertemuan $2,70 \%$ pada siklus II pertemuan 1 menjadi $85 \%$ pada siklus II pertemuan 2. Berdasarkan pembahasan setiap siklus, maka secara keseluruhan telah terjadi peningkatan hasil belajar dari silklus 1 pertemuan 1 baik pada nilia rata-rata kelas maupun persentasi ketuntasan, dimana penelitian mencapai kriteria keberhasilan saat baik nilai rata-rata kelas maupuan prosentasi ketuntasan mencapai kriteria keberhasilan, 70 dan $80 \%$, yaitu pada siklus II pertemuan 2 sebesar 84 untuk rata-rata kelas dan $85 \%$ untuk prosentase penilaian.

Saran

Berdasarkan pengalaman dalam proses perbaikan pembelajaran dengan menggunakan metode Penelitian Tindakan Kelas, Peneliti menyampaikan saran-saran sebagai berikut: (a) Penggunan model pembelajaran kooperatif tipe Think Pair Share (TPS) dapat meningkatkan keterlibatan siswa dalam proses pembelajaran untuk menemukan, memecahkan masalah dan dapat diimplementasikan dalam mata pelajaran lain; (b) Penelitian Tindakan Kelas perlu disosialisasikan kepada guru sebagai keterampilan profesional dalam pemecahan permasalahan pembelajaran; dan (c) Pengalaman dan hasil penelitian ini sebaiknya disosialisasikan sebagai bahan kajian dan masukan dalam kelompok kerja guru. 
Eli Laeli Warlina, S. Pd. SD.

Penggunaan Model Pembelajaran Kooperatif Tipe Think Pair Share (TPS) untuk

Meningkatkan Hasil Belajar Membandingkan Dua Bilangan Cacah Siswa Kelas II B SD

Negeri Pajambon

\section{DAFTAR PUSTAKA}

Depdiknas. (2006). Kurikulum tingkat satuan pendidikan (KTSP). Jakarta: PB Dharma Bakti.

Dirjen Disdakmen. (2006). Pedoman penilaian hasil belajar sekolah dasar. Jakarta: Depdiknas.

Hamalik. (1992). Media pendidikan. Bandung: Penerbit Alumni.

Hartoyo. (1999). Evaluasi hasil belajar dan pengajaran remedial. Surakarta: FKIP UNS.

Muhibbin Syah. (2004). Psikologi pendidikan dengan pendekatan baru. Bandung: Remaja Rosdakarya.

Nasution dan Sabrinah. (2003). Metode research (penelitian ilmiah). Jakarta: Bumi Aksara.

Ngadino. (1986). Media pendidikan. Jakarta: Bumi Aksara.

Roijakkers. (1982). Mengajar dengan sukses. Jakarta: Gramedia.

Sugiyono. (2002). Metode penelitian administrasi. Bandung: Alfabeta.

Suharsimi Arikunto. (2002). Prosedur penelitian: suatu pendekatan praktek. Jakarta: Rineka Cipta.

Sulistriyo. (1987). Strategi belajar mengajar. Surakarta: UNS Press.

Sumadi Suryabrata. (2003). Metodologi penelitian. Jakarta: Raja Grafindo Persada.

Sutopo. (1987). Psikologi belajar. Surakarta: Sekolah Guru Pendidikan Luar Biasa.

Sutrisno Hadi. (2002). Statistik jilid 2. Yogyakarta: Andi Offset.

UU RI No. 20. (2003). Sistem pendidikan nasional. Jakarta: DPR RI.

Winkel. (2005). Psikologi pengajaran. Yogyakarta: Media Abadi. 